\title{
The Best Way to Protect Religion against Religion
}

\author{
David Otto Endeley* \\ University of East, $U K$
}

Submission: February 10, 2017; Published: March 27, 2017

*Corresponding author: David Otto Endeley, Counter Terrorism \& Organized Crime Expert, Global Risk International, University Way, London E16 2RD, UK, Email: Davidotto@globalrisk.international-Davidotto@tgsintconsultant.com

\begin{abstract}
Traditionally, Places of worship open their doors to anyone in public to come in and worship peacefully. But people visit places of worship for varied reasons â€"some to seek for forgiveness from God and others to associate with like- minded people... With hardly any security questions asked, visitors are allowed to enter and worship within places of worship with no background and or security checks needed. The $\hat{a} €^{\sim}$ sinnerâ $€^{T \mathrm{M}}$ they come, the better for salvation to woe them into believing. At best, weekly testimonies are given when the life of criminals and sinners are turned around after seeking salvation from God through places of worship. The imminent threat of attack from Violent Extremist and Terrorist means that Places of Worship must be ready to protect their premises against those who claim to be more religious than religion itself.
\end{abstract}

\section{Introduction}

"When the hoped-for ideal is tied to a particular religious worldview and those who wish to implement their vision become convinced that they know what God wants for them and everyone else, you have a prescription for disaster".

Traditionally, Places of worship open their doors to anyone in public to come in and worship peacefully. But people visit places of worship for varied reasons - some to seek for forgiveness from God and others to associate with like-minded people... With hardly any security questions asked, visitors are allowed to enter and worship within places of worship with no background and or security checks needed. The 'sinner' they come, the better for salvation to woe them into believing. At best, weekly testimonies are given when the life of criminals and sinners are turned around after seeking salvation from God through places of worship.

Naturally, accepting a member with a criminal background into a place of worship is considered a righteous duty call from God/Allah and not a security threat. Even where previous criminal records were obvious, most violent extremist who carry out this spur-of-the-moment attacks have a clean criminal record with no previous contact with their respective state security services. Profiling specific people based on their current and previous criminal past will not help the case of detecting a friendly worshipper from one intending to cause mayhem once in the worship premise.
The reality is frightening, even the places once considered to be sanctuary in times of war, pain and need - have become a target by violent extremists and crazed fanatics. These men and women come heavily armed with AK47s... IEDs, VIEDs; suicide bombings; Knives, machetes; their sole motivation for visiting places of worship is not to pray, ask for any kind of forgiveness or associate with like-minded people. Their mission is to cause terror by destroying holy sites, maiming and killing as many innocent worshippers and religious leaders as possible in the name of God/Allah as justification.

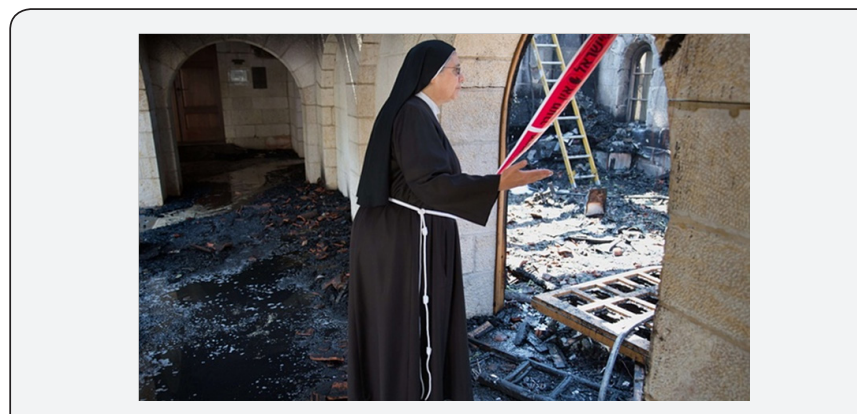

Figure 1: A catholic nun examines a destroyed place of worship.

These observations are real - and it is happening on a daily basis. Places of worship are soft targets for terrorist. Effective security measures have become imperative for implementation. The latest high profile attack - the brutal murder of the priest in Normandy - France - 86yr old Father Jacques Hamel by knifemen claiming to be soldiers of ISIL; the suicide attacks in the holy 
city of Medina - Jeddah and Qatif, and the suicide attack on Damboa Mosque North East Nigeria - are bitter reminders that soft targets, from Places of Worship, Airports; Hotels, Funerals, Shopping Centers; Public Transport; Restaurants, Markets , Cinemas, Nightclubs, Public Assembly... need full protection (Figure 1).

\section{Religion and Violence?}

It is known that "More wars have been waged, more people killed, and more evil perpetrated in the name of religion than by any other institutional force in human history. The sad truth continues in our present day" (Charles Kimball). And "Men never do evil so completely and cheerfully as when they do it from religious conviction" (Blaise Pascal 1623-1662). It is incorrect to assume that the Christian faiths of Western or European heritage are the 'good' and 'peace loving' religion and Muslims are inherently evil and wholly violent. Looking back at the European Christian nations conquering and colonization of Africa, the eventual slavery and the period of inquisition - nonbelievers in Christianity were tortured and executed for refusing to accept Jesus Christ as their savior.

It is obvious that "Terrorism is a tactic of extremists within each religion, and within secular religions of Marxism or nationalism. No religion, including Islam, preaches indiscriminate violence against innocents" (Juan Cole). History has shown that, one must be careful in pointing a wrong finger on one religious group against another. Killing innocent people under the banner of any religion at any time is morally distasteful, abhorrent and should be condemned with all rights by all men. In the current 'war against terror' the protection offered to places of worship by various national and International Humanitarian Legal framework has no significant bearing on perpetrators - both non - state actors and state actors - who violate the rights of those who visit places of worship for their own whims and caprices.

\section{Why Terrorists Attack Places of Worship?}

Some great thinkers in the past like Charles Kimball acknowledged that "When the hoped-for ideal is tied to a particular religious worldview and those who wish to implement their vision become convinced that they know what God wants for them and everyone else, you have a prescription for disaster".

Kidnapping, Suicide bombings and assault attacks in places of worship is condemned by both the laws of God and the laws of man. Recent attacks on holy places in France - Saudi Arabia and Nigeria, and a number of past coordinated attacks illustrate that places of worship have become a soft target for terrorists and other religious fanatics.

The following are some of the key reasons why places of worship are singled out:

A. Places of worship are seen as representing the physical address of a different religion to that of the perpetrator and therefore a target for damage or destruction. For example, Muslims will attack Christian churches and Christians will attack Muslim Mosque - a trend highly experience in Central Africa Republic between the Muslim majority Seleka and the Christian Majority Anti - Balaka movements. This trend is referred to as revenge attacks: where Muslims or Christians have justified attacking or burning down places of worship of the 'other' religion as a revenge for experiencing a similar act on their premise. In some occasions places of worship have been under attack as a result of the killing of a Christian or Muslim by a member of one of the denominations outside of the place of worship.

B. The spiritual leader of the targeted place of worship preaches or promotes an ideology, a worship practice that is considered contrary or opposing to that of the perpetrator.

C. A place of worship has members who are seen as sinners or apostates to the perpetrator's religion. Or simply harbors such members in their premises.

D. A place of worship keeps valuable assets and money needed by the perpetrators to service their group or sect.

E. A Place of worship is vulnerable with very little or no physical security making it naturally soft target to any type of attacks.

F. Places of worship are good soft targets for terrorist attacks because they attract maximum media propaganda needed to score the attacker or group global recognition.

\section{Recommendations}

"We cannot solve this problem only through prayers. Humans have created this problem; solve it yourself because you created it in the first place. So let us work for peace within our families and society, and not expect help from God, Buddha or the governments".

Security has never been a high priority in places of worship. But times have changed; attitudes and actions have to change. Without adequate security, attendance and activities in and around places of worship will be seriously curtailed and this will affect worshipping patterns. It is the duty of church leaders and stakeholders to protect worshippers from man-made physical harm like a terrorist or criminal attack. People should not be expected to worship in an insecure environment or rely only on prayers alone for protection from the evil of men. A security budget should be considered as a priority. Stakeholders of places of worship are advised to seek expert opinion on available integrated security solutions that will cover;
a. Security Management Committee
b. Protection of external and internal perimeter
c. Access Control systems 


\section{d. Physical security \\ e. CCTV and Alarm systems \\ f. Control Room}

\section{Security management policy}

All good meaning places of worship should adopt a comprehensive security management policy. Ideally the committee should be designed, supervised and managed by an appointed security head. The committee should in the best, include an external security consultant with specialized knowledge in protecting critical infrastructures. The main role of the committee will include selecting, and training competent members of the congregation- who will play a key role in the daily and weekly activities of the security committee. All selected members of the committee must be security vetted by an independent body, ideally by the local police service and trained to a high standard of security alertness and stranger danger.

\section{Internal perimeter}

Know your neighbors: To encourage extreme vigilance and trust, an informal policy of 'Knowing your neighbor as yourself' should be rigorously promoted between worshippers. People should be encouraged to know their immediate worship neighbors' by name. An avenue should be created where members will be encouraged to share with each other and in confidence, personal daily experiences and challenges they face in their daily lives. This will promote information sharing and encourage an atmosphere of trust and openness between worshippers.

Membership registration: The security committee could introduce a 'membership registration system' for permanent members and one off visitors. Any new worshipper or visitor MUST register to the security desk prior to gaining full access to the place of worship. A visitor's ONLY seating/standing section should be considered. If and where possible, character references should be requested to ascertain identity of new members or visitors. Ideally, existing worshippers should vouch for new worshippers if known to them. Places of worship should now consider introducing electronic photo Identity Cards for all worshippers and visitors if resources permit.

Permanent seats and standing strategy: As matter of internal strategy, and where possible, permanent seating/ standing location for worshippers should be considered. Seat allocation or relocation should be approved by a selected member of the security committee.

Data protection: Due to the sensitivity of acquired data strict in-house measures must be implemented to guard against data abuse from both internal and external parties. All data must be securely stored to avoid physical, fire, flood, cyber damages, theft or unauthorized access/interference. As a matter of internal policy, worshippers should be encouraged to leave the place of worship immediately after service and avoid loitering or creating clusters around the worship premises - such clusters are a ready target for suicide bombers and other attacks.

\section{Operational measures - lockdown and access control procedure}

Places of worship must now operate with security in mind. Each and every place of worship should have a security committee set up. The duty of the committee is to ensure that the external and internal premises or any part of a premise is secured and locked before and after use. Windows and doors should be regularly checked against any visible vulnerabilities. Any vandalism or break-in should not be concluded as 'theft motivated' simply because valuable items were stolen. High quality locking mechanisms should be used and key holders must be highly trusted and vetted. To avoid misuse, access to the premises or any part of the premises should only be possible by multiple key holders.

\section{Total vigilance/communication}

During prayer service, vigilance, overt and covert communication is key from Imams, Pastors, and Priests... members of the congregation and security officers. Ideally to avoid unwarranted sharp shooters bursting into places of worship during ongoing services - a policy to refuse members (old and new) from gaining access to a place of worship more than 30 mins after commencement of service should be introduced. Odd behaviors such as people pacing around or in the premises, running out or towards the premises, leaving bags or other items unattended should immediately alert security attention.

\section{Car park security}

Where available, all car parks must be manned by trained security operatives - car parks must be security cleared before and after services. 'Park as you like' in church premises should be avoided. Every vehicle owner should be allocated secured parking spaces away from the actual place of worship. All incoming vehicles should be scanned using appropriate and approved metal detectors and underbody vehicle scanners before they are cleared for parking. Ideally, Automatic Vehicle Number Plate Recognition System should be used (AVNPRS) for record keeping. To avoid unnecessary congestion around the premises and car parks, members that live within walking distances from the place of worship should be encouraged to walk.

\section{Counter VBIEDs}

To minimize the possibility of a Vehicle Borne Improvised Explosive Devices (VBIEDs) at places of worship, where necessary and affordable, the security committee should seriously consider appropriate security Bullard's. These Bullard's prevent forced gate crashing by a potential suicide bomber with a vehicle loaded with IEDs. VBIEDs are particularly catastrophic and can 
have the potential to kill hundreds depending on the capacity of explosives loaded in the vehicle.

\section{Crisis Management Procedures}

A. The security committee must have a crisis management procedure in place. Worshippers should be routinely reminded on some standard procedures:

B. Emergency Evacuation procedures;

C. How to react and stay calm but vigilant during an incident;

D. Mastering your exit strategy;

E. Active shooting \& taking cover techniques;

F. Surviving in hostage situations;

G. Surviving fire hazards;

H. Lockdown mechanism, and staying safe;

I. Making life or death choices- plead - flee - or fight scenarios;

J. Using emergency press buttons and making calls;

K. Overcrowding the scene of an accident or explosion should be avoided by all members and visitors;

\section{Collaboration with external partners}

As a multi-agency approach collaboration is needed for maximum safety and security. It is invaluable that places of worship should liaise through the security committee channel and work hand in gloves with the state security services. A joint multi-agency approach between inter faith groups, religious leaders, members of the congregation, external security consultants and the local police will make places of worship a hard target for terrorists and criminals if information sharing is established. A common referral procedure should be agreed and designed. Information sharing should be based on TRUST and agreed protocols. To avoid communication shut down, a place of worship or its stakeholders should NOT be a spy agent for the state security services regarding issues outside the agreed protocols.

\section{Strategic measures - secured structures}

Strategically, approved building permission should be granted to restrict random make- shift houses used as places of worship. A well-structured building will ensure security of members and staff and provide a standard platform to implement strict security measures. Church leaders must have a minimal duty of care and responsibility to the safety and security of their members and visitors when in their premises - especially at this time of heightened attacks.

\section{Awareness training}

Principally, all places of worship should introduce a welltailored security awareness 'training the trainer' program provided by both internal and external qualified security professionals- A basic program should cover: How to carry out basic risk assessment of the premises; How to spot vulnerabilities, suspicious behaviors, suspect packages, stranger dangers, enemies from within. These could be achieved using mediums like sermons, seminars and presentations tailored to the audience and delivered by trained internal or external bodies.

\section{Handling bulky items}

Worshippers and visitors should avoid taking large bags, briefcases or obscure items to places of worship - Where unavoidable, security officers should search and scan such items using approved metal detectors and bag scanners irrespective of who is in possession of the item. If logistics permit, a secured separate room for large items should be considered - a reasonable - distance from the main worship premises.

Places of worship should invest in high quality security officers and manned (remotely or on site) CCTV cameras with additional off premise control room capabilities. Obscured places including back exit doors, toilets, storage spaces, under seats, compartments must be security checked for any hidden devices or packages and cleared before and after each prayer service. All checks must cover both internal and external perimeter including; fencing patrol, access control, burglar and fire alarms, vulnerable external and internal points.

Terrorist groups survive on resources such as money, food and sales of expensive artifacts. Places of worship deal hugely in cash and they store thousands of expensive valuables from members and other donors - usually in known locations. It is therefore a very soft target and good source for terrorist needing cash and valuables to sustain the movement. Therefore, securing any cash and valuables must be top priority by well-trained security operatives. Ideally, cash or valuables should not stay in the premises for too long. If possible necessary cash securing and transit measures should be put in place or improved (1-12).

\section{Conclusion}

The above measures are not in any way exhaustive. Seeking expert and professional opinion is highly recommended at each and every stage. There is no known full proof against attacks in places of worship or other soft targets. 100\% security mitigation is not achievable but worshippers have to remember that terrorist and criminals just need one loose opportunity to get lucky. On the other hand, worshippers have to be lucky all the times. 
These are proactive preventive measures. They do not address the underlying ideology or deal with underlying motivations for attacks that occur in places of worship. A much more proactive step should encourage all religions to come together and establish an effective interfaith communication platform that will promote the detailed understanding of each faith through effective dialogues and social interaction groups. Without such platforms, the sensitivity and vulnerability of religion and its preaching of peace and justice will be hijacked by extremist, criminals and anarchist and used as an excuse to kill innocent people in places of worship. God/Allah can only help those who help themselves. Proactive prevention is always better than 'firefighting'. Remember, humans have created this problem - Do not expect God/Allah to solve it. Put your trust in us and your faith in God.

\section{References}

1. Blaise (2014) Men never do evil so completely and cheerfully as when they do it from religious conviction. French.

2. kimball, charles (2008) "when religion becomes evil: five warning signs" harper Collins, USA. pp. 1-295.

3. anti-balaka (2013) who are the anti-balaka militia groups? Central Africa, pp.1-6.

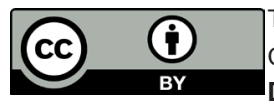

This work is licensed under Creative Commons Attribution 4.0 Licens DOI: 10.19080/JOJCS.2017.02.555589
4. The seleka (2014) Central African Republic's Seleka rebels reorganise.

5. Juan Cole (2013) Terrorism and the Other Religions. Washington Report on Middle East Affairs, USA. p. 1133.

6. Nigel Pankhurst (2016) Newspaper headlines: Priest killing, Bobby Moore plaque and 'coup d'ecat'. BBC News, USA.

7. http://www.tvm.com.mt/en/news/four-dead-insuicide-attack-in-holy-city-of-medina/

8. http://allafrica.com/stories/201607080772.html

9. http://indy100.independent.co.uk/article/what-thedalai-lama-said-when-he-was-asked-whether-weshould-pray-for-paris--w1nf_e7vkl

10. http://edition.cnn.com/2016/07/15/world/30-daysof-terror/index.html

11. http://www.badnewsaboutchristianity.com/gbg_ inquisition.htm

12. http://www.essay.uk.com/essays/law/internationalhumanitarian-law/

Your next submission with Juniper Publishers will reach you the below assets

- Quality Editorial service

- Swift Peer Review

- Reprints availability

- E-prints Service

- Manuscript Podcast for convenient understanding

- Global attainment for your research

- Manuscript accessibility in different formats ( Pdf, E-pub, Full Text, Audio)

- Unceasing customer service

Track the below URL for one-step submission https://juniperpublishers.com/online-submission.php 